This item was submitted to Loughborough's Research Repository by the author.

Items in Figshare are protected by copyright, with all rights reserved, unless otherwise indicated.

\title{
The impact of a design management training initiative on project
} performance

PLEASE CITE THE PUBLISHED VERSION

PUBLISHER

(c) Emerald

LICENCE

CC BY-NC-ND 4.0

REPOSITORY RECORD

Bibby, Lee, Dino Bouchlaghem, and Simon A. Austin. 2019. "The Impact of a Design Management Training Initiative on Project Performance”. figshare. https://hdl.handle.net/2134/3893. 
This item was submitted to Loughborough's Institutional Repository (https://dspace.lboro.ac.uk/) by the author and is made available under the following Creative Commons Licence conditions.

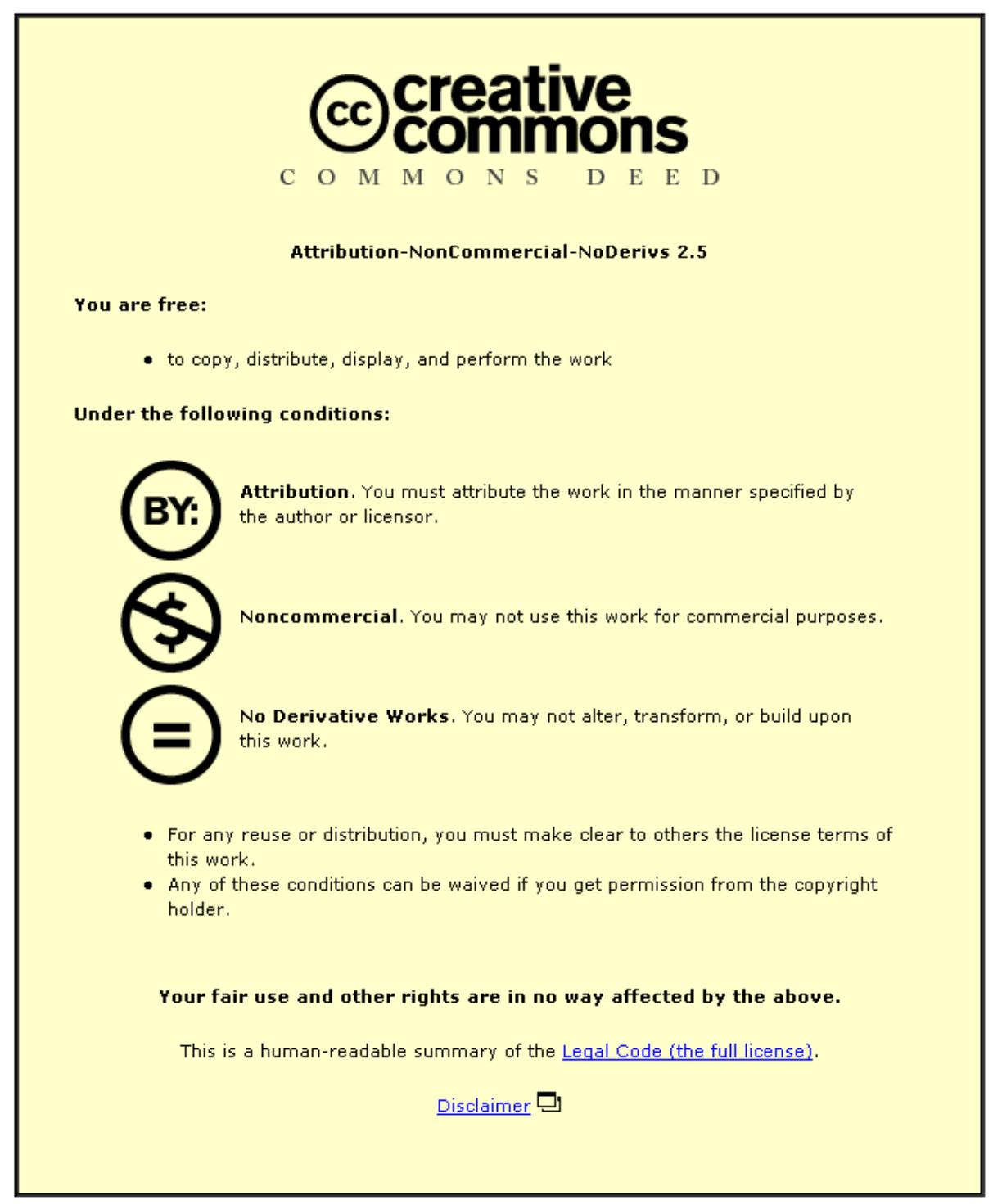

For the full text of this licence, please go to: http://creativecommons.org/licenses/by-nc-nd/2.5/ 


\title{
THE IMPACT OF A DESIGN MANAGEMENT TRAINING INITIATIVE ON PROJECT PERFORMANCE \\ L. Bibby, S. Austin and D. Bouchlaghem ${ }^{1}$
}

\begin{abstract}
Over recent years there has been a significant drive away from traditional procurement routes where contractors find themselves with an increasing responsibility for the control of the design - a process they have had little experience in managing. Yet this is an area of significant opportunity for those contractors who can adapt quickly and effectively to the changing construction market. However, many current processes are insufficient to manage today's demanding and fast moving projects.

The paper reflects on the deployment of a design management training initiative to improve performance in a major UK civil and building design and construction company. It investigates the impact of the training initiative, critical practices and a suite of 25 tools on design management performance across the company. It highlights benefits delivered by the initiative as well as the practices and tools crucial to successful design management. The paper also explores the range, significance and hierarchy of implementation barriers that affect the success of design management practices and reports on strategies that have been used on a case study project to overcome such barriers. The paper is likely to be of interest to those involved in design management and the development of tools and practices to help the industry improve design management performance.
\end{abstract}

Keywords: construction, design, management, industry practice, process, tools, training.

\section{INTRODUCTION}

To reduce their risks associated with construction projects clients are increasingly adopting design and build type procurement routes in favour of traditional contracts. As a result, contractors are now expected to accept an increasing responsibility for the control of design - a process they have had little experience in managing. They now have to adapt accordingly. The learning curve is steep, not least because many projects must now be delivered fast track while co-ordinating the increasingly complex fabric (Austin et al, 1996) and content of buildings without a platform of accepted good practice to manage the design process. This is a major factor preventing the UK construction industry from delivering projects on time, to budget and to the specified quality.

As the target is to increase Design \&Build projects to a $50 \%$ share of the UK construction market by 2008 (Egan et al, 2002) it is necessary to educate an increasing number of people in design management practices and tools to equip them to manage today's fast moving and demanding projects. However, many current design management tools are insufficiently developed for the industry (Bibby, et al, 2003b). 
They are fragmented, insufficiently developed, poorly deployed and couched in abstract terms (Freire and Alarcon, 2000; Frost, 1999). Moreover, as they tend to be overly complex and force practitioners into unwanted procedures (Kanter, 2000), they are unlikely to gain wide adoption. Therefore, to improve design management in the industry, current techniques must be modified to align them with the needs of the modern design manager to manage the construction design process.

Previous research (Bibby et al, 2003b) has developed a training initiative to improve design management within a major design and construction company with interests in PFI, Prime Contracting, D\&B as well as traditional contracting. For the past three years, through a partnership with Loughborough University and the Engineering and Physical Sciences Research Council (EPSRC), this research has been applying a new approach to design management to adapt to the changing UK construction market.

The initiative comprises a Design Management Handbook, Design Management Training, Team Support and Project Monitoring. The Design Management Handbook is the core of the training initiative. It provides guidance on critical aspects of design management practice and a suite of twenty-five tools. Training on practices and tools has been provided to approximately 600 employees across project teams throughout the company. Project teams have been supported in the implementation of the new practices and tools through Team Support to help embed new ways of working in company practice. Project Monitoring has helped establish the impact of the new practices on project performance to demonstrate that they are working and thus reinforce change.

The effectiveness of the training initiative on the company's design management performance has been explored through a combination of questionnaires, semistructured interviews, maturity assessment and a case study. This has established which practices and tools are being used, which ones are not, as well as understanding the applicability and performance of each practice and tool. It has also identified the barriers to implementing new design management tools in the industry as well as developing and testing strategies to overcome such barriers.

While the training initiative was undertaken to suit the needs of a major D\&B contractor, its development was influenced by best practice within and outside the industry, as well as common barriers identified in the literature (Bibby et al, 2002). Hence, lessons learned in this paper should be widely applicable to those involved in design management and the development of tools and practices to help the industry improve design management performance. Research to quantify the impacts of success factors has been limited, particularly with respect to design performance (Kuprenas, 2003). Whilst the findings are based on a single organisation, the work carried out represents a significant step forward for the industry in developing strategies to deliver improvements to design management performance. 


\section{RESEARCH METHODOLOGY}

The research in this paper sought to establish the impact of the design management training initiative on individual and project performance. The methodology comprised a structured questionnaire, design management maturity assessment, semi-structured interviews and a case study investigation.

The structured questionnaire identified who out of 46 employees exposed to the training initiative as part of a pilot study had used the design management handbooks practices and tools. This was to identify who was to be interviewed in more detail, why others did not use the handbook and their views on the awareness training. Interviewees comprised 15 Design Managers 5 Project Planners, 8 Quantity Surveyors, 5 Project Directors, 5 Project Managers, 3 Bid Managers, 2 Systems Managers, 1 Document Controller and 2 Procurement Managers spread over 14 projects. Good practice in preparing and conducting the questionnaire was used in this research (Race, 2001; Fellows and Liu, 1997).

The maturity assessment used a Design Management Maturity Model shown in Figure 1 and conceptually based on the Capability Maturity Model (Rosenstock, Johnston, \& Anderson, 2000; Skulmoski, 2001) which has widespread acceptance as a standard for assessment of organisational maturity (Crawford, 2002). It is a two dimensional matrix with the horizontal and vertical axes representing the level of maturity (between 1 and 5) and the key areas of design management respectively. The nine key design management areas and their maturity levels were defined using references to previous work (Bibby et al, 2002; Bibby et al, 2003b) and a model developed to test the maturity of design supply chains (Austin et al, 2001).

The assessment was carried out in three stages. The first and second stages were carried out immediately before and after all 46 respondents received awareness training. This was to establish the change in opinion on the company's design management performance caused by the training. The final assessment took place as part of the semistructured interview exercise and aimed to capture the change in design management maturity delivered by the training initiative. As this final assessment was carried out with those that had used design management handbook practices and tools, only these results have been used to identify the impact of the training initiative on design management maturity within the company. While it would have been preferable to capture the opinion of all 46 respondents at the final assessment stage, the results are still considered valid as the exercise captured the change in opinion of individuals on the company's design management maturity over the period of the training initiative. 


\begin{tabular}{|c|c|c|c|c|c|}
\hline & $\begin{array}{c}\text { Level } 1 \\
\text { Haven't thought about it }\end{array}$ & $\begin{array}{c}\text { Level } 2 \\
\text { Thinking of doing } \\
\text { something about it }\end{array}$ & $\begin{array}{c}\text { Level } 3 \\
\text { Beginning to do } \\
\text { something about it }\end{array}$ & $\begin{array}{c}\text { Level } 4 \\
\begin{array}{c}\text { Doing it as normal } \\
\text { business }\end{array}\end{array}$ & $\begin{array}{c}\text { Level } 5 \\
\begin{array}{c}\text { Advanced practices } \\
\text { developed }\end{array}\end{array}$ \\
\hline $\begin{array}{l}\text { establishing and } \\
\text { communicating design } \\
\text { briefs }\end{array}$ & $\begin{array}{l}\text { no process to establish and } \\
\text { communicate project } \\
\text { design briefs }\end{array}$ & $\begin{array}{l}\text { inconsistent approach to } \\
\text { establishing and } \\
\text { communicating project } \\
\text { design briefs }\end{array}$ & $\begin{array}{l}\text { collaboratively ensure all } \\
\text { stakeholders needs are } \\
\text { articulated, captured and } \\
\text { understood before phase } \\
\text { begins }\end{array}$ & $\begin{array}{l}\text { consistently establish and } \\
\text { communicate work scope } \\
\text { and delivery details for } \\
\text { whole project }\end{array}$ & $\begin{array}{l}\text { consistently establish and } \\
\text { communicate work scope } \\
\text { and delivery details for } \\
\text { whole project and individual } \\
\text { disciplines }\end{array}$ \\
\hline \begin{tabular}{|l|} 
design management \\
roles and responsibilities
\end{tabular} & $\begin{array}{l}\text { no consideration given to } \\
\text { defining the roles and } \\
\text { responsibilities of a design } \\
\text { manager }\end{array}$ & $\begin{array}{l}\text { ad-hoc approach to } \\
\text { defining roles and } \\
\text { responsibilities of a design } \\
\text { manager }\end{array}$ & $\begin{array}{l}\text { roles and responsibilities of } \\
\text { a design manager defined }\end{array}$ & $\begin{array}{l}\text { roles and responsibilities of } \\
\text { design manager and the } \\
\text { involvement of other parties } \\
\text { in design management } \\
\text { defined }\end{array}$ & $\begin{array}{l}\text { all parties aware of their } \\
\text { potential contribution to and } \\
\text { involvement in design } \\
\text { management }\end{array}$ \\
\hline selecting team members & $\begin{array}{l}\text { no selection process used } \\
\text { to identify suitable design } \\
\text { team members }\end{array}$ & $\begin{array}{l}\text { inconsistent approach to } \\
\text { assessing and selecting } \\
\text { potential design team } \\
\text { members }\end{array}$ & $\begin{array}{l}\text { structured means to identify } \\
\text { and assess consultant's } \\
\text { skills }\end{array}$ & \begin{tabular}{|l|} 
structured means to \\
differentiate assessed skills \\
of consultants to select a \\
preferred consultant
\end{tabular} & $\begin{array}{l}\text { performance data used to } \\
\text { assess consultant skills } \\
\text { and determine selection }\end{array}$ \\
\hline $\begin{array}{l}\text { integrated design } \\
\text { planning }\end{array}$ & $\begin{array}{l}\text { design is planned } \\
\text { separately from the } \\
\text { procurement and } \\
\text { construction processes }\end{array}$ & $\begin{array}{l}\text { major design activities } \\
\text { planned with consideration } \\
\text { of construction } \\
\text { requirements }\end{array}$ & $\begin{array}{l}\text { major design, procurement } \\
\text { and construction activities } \\
\text { linked and integrated }\end{array}$ & \begin{tabular}{|l|} 
individual design activities \\
of all disciplines integrated \\
with each other and \\
construction activities
\end{tabular} & $\begin{array}{l}\text { resource allocation } \\
\text { considered on integrated } \\
\text { project programmes }\end{array}$ \\
\hline ensuring design delivery & $\begin{array}{l}\text { no effort to manage the } \\
\text { distribution of design } \\
\text { deliverables }\end{array}$ & $\begin{array}{l}\text { document management } \\
\text { recognised as a major task } \\
\text { that must be improved }\end{array}$ & $\begin{array}{l}\text { inconsistent management } \\
\text { of the production and issue } \\
\text { of design deliverables }\end{array}$ & $\begin{array}{l}\text { consistent management of } \\
\text { the production and issue of } \\
\text { design deliverables }\end{array}$ & $\begin{array}{l}\text { range of approaches to } \\
\text { manage the production and } \\
\text { issue of design deliverables } \\
\text { to all parties }\end{array}$ \\
\hline $\begin{array}{l}\text { managing information } \\
\text { flow }\end{array}$ & $\begin{array}{l}\text { design information } \\
\text { distributed to all parties } \\
\text { without consideration of } \\
\text { needs }\end{array}$ & $\begin{array}{l}\text { recognised overload of } \\
\text { information flow and need } \\
\text { to improve practices }\end{array}$ & $\begin{array}{l}\text { information distributed } \\
\text { based on issuers } \\
\text { perception of recipient } \\
\text { needs }\end{array}$ & $\begin{array}{l}\text { information needs of each } \\
\text { party understood with } \\
\text { parties able to access } \\
\text { essential information }\end{array}$ & $\begin{array}{l}\text { fully co-ordinated needs } \\
\text { expressed: specific } \\
\text { information requirements } \\
\text { and why each is needed. }\end{array}$ \\
\hline developing the design & $\begin{array}{l}\text { design development } \\
\text { undertaken in uncontrolled } \\
\text { manner and designers } \\
\text { working in isolation }\end{array}$ & $\begin{array}{l}\text { inconsistent design } \\
\text { development but designers } \\
\text { collaborating on major } \\
\text { issues }\end{array}$ & $\begin{array}{l}\text { structured approach to } \\
\text { design development and } \\
\text { designers collaborating on } \\
\text { most issues }\end{array}$ & \begin{tabular}{|l} 
structured approach to \\
design development and \\
designers collaborating \\
where necessary
\end{tabular} & $\begin{array}{l}\text { design team operating } \\
\text { within fully integrated and } \\
\text { collaborative design } \\
\text { environment }\end{array}$ \\
\hline $\begin{array}{l}\text { value consideration in } \\
\text { design process }\end{array}$ & $\begin{array}{l}\text { no consideration of value in } \\
\text { design development } \\
\text { process }\end{array}$ & $\begin{array}{l}\text { aware that can and should } \\
\text { be considering value in the } \\
\text { design process }\end{array}$ & $\begin{array}{l}\text { inconsistent approach } \\
\text { using value analysis } \\
\text { techniques in the design } \\
\text { process }\end{array}$ & $\begin{array}{l}\text { phased set of value } \\
\text { analysis activities } \\
\text { structured into the design } \\
\text { process }\end{array}$ & $\begin{array}{l}\text { value generation process } \\
\text { undertaken as an intrinsic } \\
\text { part of the design } \\
\text { development process }\end{array}$ \\
\hline $\begin{array}{l}\text { managing design } \\
\text { changes }\end{array}$ & $\begin{array}{l}\text { design changes } \\
\text { implemented by instruction }\end{array}$ & $\begin{array}{l}\text { inconsistent approach to } \\
\text { the assessment of design } \\
\text { change proposal }\end{array}$ & \begin{tabular}{|l|} 
consider design changes \\
proposals by identifying and \\
assessing significant \\
impacts
\end{tabular} & \begin{tabular}{|l|} 
design proposals assessed \\
consistently using \\
structured process to \\
identify and assess time, \\
cost and quality impacts
\end{tabular} & \begin{tabular}{|l|} 
ability to quickly and \\
effectively explore potential \\
design change options
\end{tabular} \\
\hline
\end{tabular}

Figure 1: Design Management Maturity Assessment Model

Semi-structured interviews captured the impact of the practices and tools presented by the training initiative on individual and project performance as well as the difficulties people had in applying the practices and tools. The views on the Design Management Handbook, the Awareness Training and a Design Management Intranet site set up as part of the training initiative were also sought. This approach avoided the potential for bias and difficulty in coding data associated with structured interviews and unstructured interviews respectively.

The 20 interviewees comprised 14 Design Managers, a Quantity Surveyor, a Project Director, a Project Manager, a Bid Manager, a Systems Manager and a Document 
Controller spread over 8 projects. Good practice in preparing and conducting interviews was used in this research (Race, 2001; Fellows and Liu, 1997).

To understand the impacts of, and the barriers to using each of the design management practices and tools, interview results were coded and analysed in four steps:

Step 1: impacts and barriers identified by interviewees for each practice and tool were categorised into 14 separate impacts (critical and supportive) and 23 separate barriers (selection, pre-application and application barriers) respectively. Critical impacts are primary project goals related to time, cost and quality, e.g. a design meeting all client requirements. Supportive impacts are precursors to achieving critical impacts; e.g. project team members are collaborating. Selection barriers will stop a user choosing to use a tool; e.g., a tool might not be appropriate for the procurement route being considered. Preapplication barriers dissuade users from applying a tool in the belief that project circumstances would prevent it from being successful. E.g., a lack of agreed project design management processes could prevent a change control process being introduced as it may not be recognised or used by other project team members. Application barriers are those barriers that affect the successful operation of a tool in use. E.g., project parties not collaborating can have a significant effect on focusing development early in the process.

Step 2: Equation 1 was used to establish the percentage $\left(\mathrm{P}_{1}\right)$ of respondents using each practice / tool that reported an impact. Equations 2, 3 and 4 were used to identify the percentage of respondents who identified the selection, preapplication and application barrier at the choice, preparation and implementation stage of each practice and tool - $\mathrm{P}_{2}, \mathrm{P}_{3}$, and $\mathrm{P}_{4}$ respectively. These four equations helped identify the relative significance that each impact and barrier has.

Step 3: To highlight which impacts and barriers were most significant it was necessary to differentiate impacts identified by a few from those identified bythe majority. Equation 5 was developed and used to obtain a weighted score for each impact and barrier.

Step 4: The weighted scores in each category (critical and supportive impacts, selection, pre-application and application barriers) were ranked and cumulative percentage graphs of the weighted scores prepared. This identified the impacts / barriers that represented $80 \%$ of the maximum cumulative weighting score in each category and thus which can be considered the most significant.

\footnotetext{
$\mathrm{P}_{1}=\frac{\sum \text { practice } / \text { tool had positive project impact }}{\sum \text { used practice } / \text { tool }} \times 100 \quad \mathrm{P}_{3}=\frac{\sum \text { pre-application barrier reported against practice } / \text { tool }}{\sum \text { not had opportunity to use practice } / \text { tool }} \times 100$

$\mathrm{P}_{2}=\frac{\sum \text { selection barrier reported against practice } / \text { tool }}{\sum \text { did not need to use practice / tool }} \times 100 \quad \mathrm{P}_{4}=\frac{\sum \text { application barrier reported against practice / tool }}{\sum \text { used practice / tool }} \times 100$
}

Equations 1, 2, 3 and 4: Equations for calculating $\mathrm{P}_{1}, \mathrm{P}_{2}, \mathrm{P}_{3}$, and $\mathrm{P}_{4}$ 


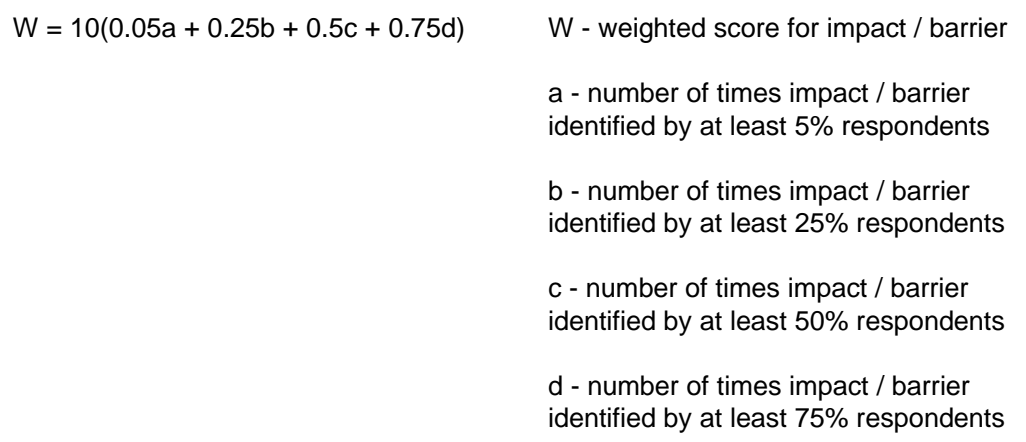

Equation 5: Weighted Score for Design Management Impact or Barrier

The case study was undertaken to help understand at first hand issues and barriers to deployment of design management practices and tools. The project team was supported in implementing practices and tools. The views of the project team, client and designers were sought throughout the exercise to determine the appropriate tools, how they integrated with other project processes, whether any modifications or additions were required and how to overcome the selection, pre-application and application barriers.

\section{DESIGN MANAGEMENT AWARENESS TRAINING}

The awareness training (where practices and tools are presented) was well received as illustrated by Table 1. Many believed it helped to appreciate design management issues by expanding and clarifying their own ideas and covered all issues in a detailed and methodical way. Interviewees liked the open forum presentation style that allowed discussion of issues by all project team members. It also helped them work with the design management team and designers by explaining the benefits of practices / tools as well as explaining designers' needs and difficulties which has helped to break down professional friction (or conflicts) that can hinder team working (Baldwin and Jarrett, 2002).

\begin{tabular}{|l|c|c|c|c|c|c|c|c|}
\cline { 2 - 9 } \multicolumn{1}{c|}{} & \multicolumn{2}{|c|}{$\begin{array}{c}\text { It has helped me } \\
\text { appreciate DM } \\
\text { issues }\end{array}$} & $\begin{array}{c}\text { It has helped me } \\
\text { work with DM team } \\
\text { and designers }\end{array}$ & \multicolumn{2}{c|}{$\begin{array}{c}\text { It has improved my } \\
\text { performance }\end{array}$} & $\begin{array}{c}\text { It has improved } \\
\text { project performance }\end{array}$ \\
\cline { 2 - 10 } & total & $\%$ & total & $\%$ & total & $\%$ & total & $\%$ \\
\hline strongly disagree & 0 & $0 \%$ & 0 & $0 \%$ & 0 & $0 \%$ & 0 & $0 \%$ \\
\hline disagree & 0 & $0 \%$ & 1 & $2 \%$ & 2 & $4 \%$ & 2 & $4 \%$ \\
\hline neutral & 4 & $9 \%$ & 7 & $15 \%$ & 8 & $17 \%$ & 23 & $50 \%$ \\
\hline agree & 33 & $72 \%$ & 32 & $70 \%$ & 31 & $67 \%$ & 21 & $46 \%$ \\
\hline strongly agree & 9 & $20 \%$ & 6 & $13 \%$ & 5 & $11 \%$ & 0 & $0 \%$ \\
\hline
\end{tabular}

Table 1: Comments on Design Management Awareness Training

Over three-quarters of interviewees consider that their personal performance was improved by attending the awareness training. Several said it helped understand the design process, its issues and potential bottlenecks in detail; showed how to prepare a good design programme and emphasised the need for the whole project team to respect the design freeze process. Almost half of interviewees said the awareness training positively affected project performance by getting the construction team to understand design management and the whole team to question and improve design management 
and other project processes. Several suggested that design process improvements were difficult to identify as they were masked by the activities of other project members. For example, when a designer issued drawings early, subsequent procurement and construction activities were not ready to use the drawings - resulting in lost improvements. Also, several interviewees noted that designers were reluctant to plan the design in detail and the client was not respecting the design freeze process. Such examples illustrates the effect of departmentalising in sub-optimising the design process in line with Womack and Jones' (1996) lean thinking and reinforces the findings of earlier work (Bibby et al, 2003a) that design management can be significantly affected by the actions of others in the "project system".

One unanticipated comment repeated by several interviewees was that the mere presence of the researcher within the company had a positive impact on design management performance. By being a persistent champion for design management it has raised the awareness of design management and acted as an impetus for change across the company. It may have also addressed a key problem of training noted by (Beer et al, 1993) that employees often become frustrated when their new skills go unused in an organisation where nothing else has changed - thus undermining commitment to change. However, as the presence of the researcher has maintained the momentum of the change programme this has helped to address such barriers.

Several conclusions can be drawn from these observations. The awareness training has been successful by getting the project team to understand design management, to work with design management / design teams and has improved their personal performances. Also, the presence of the researcher within the organisation has acted as an impetus for change. However, process improvements can be hidden by other project operations. Therefore, future projects should include the design team and client in awareness training, delivered at each project start up and involve the agreement of project design management processes. This helps ensure a consistent process (Kagioglou et al, 1998) and allows genuine involvement which is essential for introducing new ways of working (White, 1979). It is therefore a good strategy for addressing pre-application barriers. On the case study project all parties commented on and agreed design management processes, which has helped to embed the practices and tools in the project processes.

\section{DESIGN MANAGEMENT HANDBOOK, PRACTICES AND TOOLS}

\subsection{Use of the Handbook}

The overwhelming majority (14/15) of design managers did use the handbook with only one unable to do so because of lack of time and supporting resources to prepare tools for his project. Encouragingly 6 non-design managers also used the Design Management Handbook practices and tools. The remaining 26 interviewees did not use the practices and tools: 12 did not need to use it as part of their work and 14 did not have the opportunity to use the practices and tools. This was due to one of the following:

- the practice or tool being introduced too late for use in the project process;

- current processes not written to suit application of the tools; or

- that interviewees lacked the time or resources to put the tool into place. 
However, some said they would use the Handbook in future if processes were mandatory, if all project operations were involved in defining project design management processes, and if more project time was allowed to develop processes.

The first two barriers were addressed on the case study project by involving all project disciplines in the selection of design management processes and their definition in a mandatory Project Design Management Plan (PDMP). As a lack of time is a common design phase problem (Austin et al, 1996), it is unlikely that more will be available to develop processes. However, the case study comments suggest that using a model PDMP will require less time to define processes.

The Handbook tools were taken by the company and included in its Integrated Management System (IMS) available through the company Intranet. Few interviewees used it as it did not provide anything in addition to the Handbook, there were some initial access problems and many considered the format made it difficult to navigate the IMS.

In conclusion, design managers are clearly using the Handbook and other project disciplines are also starting to adopt it. Case study experience has shown that the deployment of a PDMP can help overcome implementation barriers.

\subsection{Handbook Content and Format}

Table 2 shows interviewees comments on the Handbook. An overwhelming majority considered that the handbook had a clear and logical format, which was also easy to read and understand. Many also liked the standalone format of each section containing all guidance for that subject area and directed users to the associated tools. The majority believed that the handbook provided a good understanding of the subject and showed how to manage the design process by providing good practice that can be applied relatively easily and explaining how to overcome typical design management problems.

\begin{tabular}{|l|c|c|c|c|c|c|c|c|}
\cline { 2 - 9 } & \multicolumn{2}{c|}{$\begin{array}{c}\text { Has a clear and } \\
\text { logical format }\end{array}$} & \multicolumn{2}{c|}{$\begin{array}{c}\text { Is easy to read and } \\
\text { understand }\end{array}$} & \multicolumn{2}{c|}{$\begin{array}{c}\text { Gives me a good } \\
\text { understanding of } \\
\text { subject }\end{array}$} & $\begin{array}{c}\text { Shows how to } \\
\text { manage the } \\
\text { design }\end{array}$ \\
\cline { 2 - 10 } & total & $\%$ & total & $\%$ & total & $\%$ & total & $\%$ \\
\hline strongly disagree & 0 & $0 \%$ & 0 & $0 \%$ & 0 & $0 \%$ & 0 & $0 \%$ \\
\hline disagree & 0 & $0 \%$ & 1 & $5 \%$ & 1 & $5 \%$ & 2 & $10 \%$ \\
\hline neutral & 1 & $5 \%$ & 4 & $20 \%$ & 5 & $25 \%$ & 1 & $5 \%$ \\
\hline agree & 16 & $80 \%$ & 11 & $55 \%$ & 10 & $50 \%$ & 15 & $75 \%$ \\
\hline strongly agree & 3 & $15 \%$ & 4 & $20 \%$ & 4 & $20 \%$ & 2 & $10 \%$ \\
\hline
\end{tabular}

Table 2: Comments on the Design Management Handbook

Table 3 shows that there were no problems reported related to the content and style of any practice or tool, therefore, the Handbook appear to be a useful tool to diffuse design management practices and tools throughout the company.

\subsection{Use of Design Management Practices and Tools}

There is an interesting picture of use and success of design management practices and tools amongst interviewees, principally illustrated in Tables 3, 4 and 5. Table 3 shows 
the level of use of design management practices and tools amongst interviewees. The values shown are the percentages of interviewees who agreed with the statements in the table against each practice and tool. Table 4 shows the critical and supportive impacts that were provided by each practice and tool. The values shown are the percentages of the interviewees that had used a practice / tool that reported a positive impact delivered by the practice or tool. Table 5 illustrates the selection, pre-application and application barriers that affected the performance of each design management practice and tool. For selection barriers the values represent the percentages of interviewees that did not need to use a practice / tool as part of their work and reported that a selection barrier caused them not to use it. For pre-application barriers the values represent the percentages of interviewees that did not have the opportunity to use a practice / tool and stated that this was caused by a pre-application. For application barriers the value represents the percentages of interviewees that used a practice / tool stating that an application barrier affected the performance. Values in all tables recorded as $0 \%$ have been omitted for clarity. The cells in the tables have also been shaded following the key shown by each table for clarity.

Generally, interviewees have used the design management practices and tools with many reporting positive personal and project performance impacts. All practices, apart from Rigorous Team Selection provided between three and five critical project impacts. Therefore, they are crucial to effective design management. The following practices delivered significant levels of critical and supportive impacts and as such are the foundations of design management: capturing, clarifying and owning stakeholder requirements; progressive freezing of design details; be more specific with design scope of works; involve parties at the right time in the process; monitor all design deliverables; control issues of deliverables and information.

As few interviewees undertook Rigorous Team Selection or used associated tools P07 Consultant Benchmarking, and P08 Consultant Interviews, it is difficult to establish their importance to effective design management. This activity is typically the responsibility of the company's senior management. Comments suggested they did not carry out design team selections in the rigorous and structured manner suggested by the Handbook. However, many believed that it is an important design management task and that the company should do it more rigorously. From this, it would appear that senior management have not taken the opportunity to take the lead to apply new design management processes.

Table 4 shows the practices against which users reported a low instance of positive impacts. These practices are: allowing adequate design time, planning the design in detail and collaboratively, managing interfaces, investigating and controlling potential design changes, and focusing development effort early in the process. This appears to be the affect of a combination of barriers at pre-application and application stages. The pre-application stage barrier affecting all practices is the lack of leadership from senior management. However, during application there are four common barriers affecting the practices: lack of leadership from senior management, construction team ignoring design freeze / change control, client ignoring design freeze / change control and parties not collaborating. 

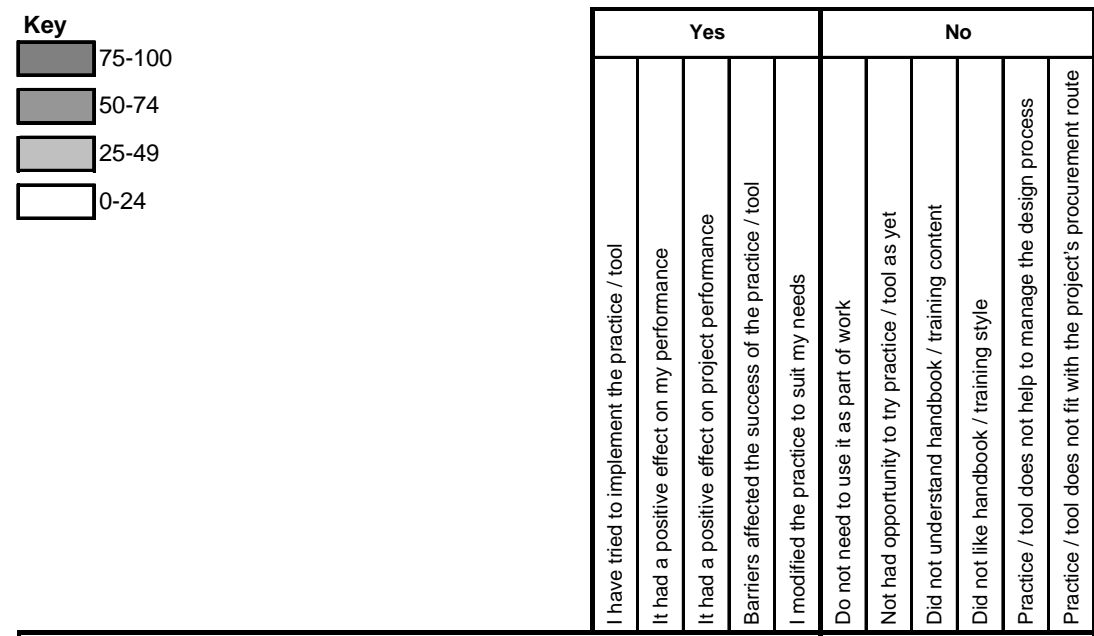

design management practices

\begin{tabular}{|c|c|c|c|c|c|c|c|c|c|}
\hline Rigorous team selection based on range of criteria & 15 & 15 & 15 & 75 & 5 & 75 & 10 & & \\
\hline Capturing, clarifying and owning stakeholder requirements & 80 & 80 & 60 & 35 & & & 20 & & \\
\hline Understanding the process of design in detail & 95 & 85 & 65 & 35 & & & 5 & & \\
\hline Allow adequate design time & 65 & 35 & 25 & 80 & & & 35 & & \\
\hline Plan the design in detail and collaboratively & 80 & 65 & 55 & 50 & & & 20 & & \\
\hline Integrate design, procurement and construction activities & 85 & 70 & 70 & 40 & & & 15 & & \\
\hline Progressive freezing of design details & 80 & 65 & 65 & 50 & & & 20 & & \\
\hline Be more specific with design team scope of works & 90 & 85 & 70 & 30 & & & 10 & & \\
\hline Control issue of deliverables and information & 90 & 80 & 65 & 45 & & & 10 & & \\
\hline Manage interfaces & 75 & 65 & 55 & 65 & & & 25 & & \\
\hline Investigate and control potential design changes & 65 & 55 & 40 & 75 & & & 35 & & \\
\hline Focus development effort early in the process & 80 & \begin{tabular}{|l|l}
55 \\
\end{tabular} & 55 & 75 & & & 20 & & \\
\hline Involve parties at the right time in the process & 80 & 80 & 80 & 30 & & & 20 & & \\
\hline Monitor all design tasks and deliverables & 80 & 75 & 80 & 25 & & & 20 & & \\
\hline \multicolumn{10}{|c|}{ planning tools } \\
\hline P01 brief document & 80 & 80 & 70 & 15 & 25 & & 20 & & \\
\hline P02 concept design stage kick-off meeting & 15 & 15 & 15 & 75 & 5 & 75 & 10 & & 70 \\
\hline P03 tender design stage kick-off meeting & 25 & 25 & 25 & 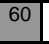 & 15 & & 75 & & \\
\hline P04 detailed design stage kick-off meeting & 15 & 15 & 15 & 60 & 10 & 55 & 25 & & 50 \\
\hline P05 design change workshop & 35 & 30 & 30 & 60 & & & 65 & & \\
\hline P06 master design programme & 65 & 65 & 50 & 55 & & 15 & 20 & & \\
\hline P07 consultant benchmarking & 5 & 5 & 5 & 90 & & 85 & 10 & & \\
\hline P08 consultant interviews & 5 & 5 & 5 & 95 & & 85 & 10 & & \\
\hline P09 discipline design programme & 65 & 65 & 65 & 30 & & 10 & 25 & & \\
\hline P10 job description & 5 & 5 & & 55 & & 95 & & 30 & \\
\hline co-ordin & tool & & & & & & & & \\
\hline C01 information transfer schedule & 85 & 85 & 75 & \begin{tabular}{l|l}
15 \\
\end{tabular} & 35 & & 15 & & \\
\hline C02 work package control document & 75 & 75 & 70 & 5 & 35 & & 25 & & \\
\hline co-ordination meeting & 95 & 90 & 80 & 20 & 30 & & 5 & & \\
\hline C04 design workshop & 65 & 65 & 65 & \begin{tabular}{c|c}
10 \\
\end{tabular} & 15 & & 35 & & \\
\hline C05 staged information delivery & 40 & 40 & 35 & 10 & 5 & 5 & 55 & & \\
\hline fix information & 40 & 40 & 30 & 30 & 15 & 5 & 55 & & \\
\hline C07 interface schedule & 40 & 40 & 30 & 30 & 15 & 5 & 55 & & \\
\hline developr & tools & & & & & & & & \\
\hline D01 value analysis & 45 & 45 & 45 & 50 & 5 & & 55 & & \\
\hline D02 brainstorming & 65 & 65 & 60 & & 10 & 15 & 20 & 10 & \\
\hline D03 decision matrix & 5 & 5 & 5 & 55 & & 60 & 35 & 60 & \\
\hline D04 task force meeting & & & & 40 & & 50 & 50 & 40 & \\
\hline D05 design review document & 30 & 30 & 30 & 10 & 20 & 15 & 55 & & \\
\hline D06 design proposal document & 30 & 30 & 30 & 30 & 20 & 15 & 55 & & \\
\hline
\end{tabular}

Table 3: Use of Design Management Practices and Tools 

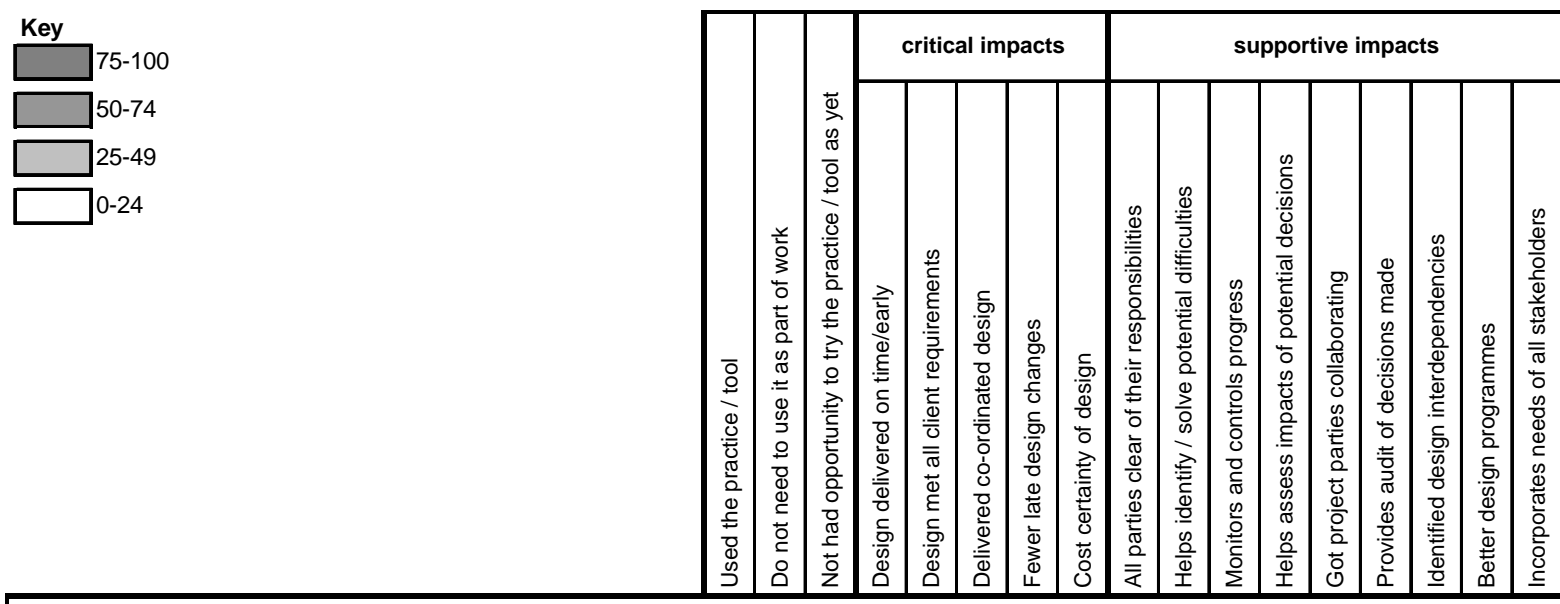

design management practices

\begin{tabular}{|c|c|c|c|c|c|c|c|c|c|c|c|c|c|c|c|c|c|}
\hline \multirow{2}{*}{$\begin{array}{l}\text { Rigorous team selection based on range of criteria } \\
\text { Capturing, clarifying and ownership of stakeholder requirements }\end{array}$} & 15 & 75 & 10 & & & & & & & 65 & & & & 35 & & & \\
\hline & 80 & & 20 & 50 & 55 & 5 & 25 & 30 & 30 & 5 & & & 5 & & & & \\
\hline Understanding the process of design in detail & 95 & & 5 & 5 & & 20 & 10 & & & 35 & & & 30 & & 45 & & \\
\hline Allow adequate design time & 65 & & 35 & 15 & 10 & 10 & & 10 & & 15 & & & & & 10 & 15 & \\
\hline Plan the design in detail and collaboratively & 80 & & 20 & 30 & & 45 & & & 25 & 25 & & 15 & 45 & & 20 & 20 & \\
\hline Integrate design, procurement and construction activities & 85 & & 15 & 45 & & 45 & 5 & & 20 & 10 & & 5 & 35 & & 5 & 5 & \\
\hline Progressive freezing of design details & 80 & & 20 & 75 & & 30 & 55 & 5 & & & & & 15 & & & & \\
\hline Be more specific with design team scope of works & 90 & & 10 & 50 & 50 & & 50 & & 45 & 5 & 5 & & 5 & & & & \\
\hline Control issue of deliverables and information & 90 & & 10 & 60 & 40 & 5 & 10 & & 55 & & & & & & & & \\
\hline Manage interfaces & 75 & & 25 & 5 & & 15 & 5 & & 55 & & & & 5 & & 45 & & \\
\hline Investigate and control potential design changes & 65 & & 35 & 25 & & & 30 & 10 & 15 & & & 60 & 10 & & & & \\
\hline Focus development effort early in the process & 80 & & 20 & 55 & 15 & 5 & 5 & 40 & & 5 & & & & & & & \\
\hline Involve parties at the right time in the process & 80 & & 20 & 90 & 50 & 40 & 55 & 30 & & 65 & & & 40 & & & & \\
\hline Monitor all design tasks and deliverables & 80 & & 20 & 50 & & & & & 45 & 45 & 70 & & & & & & \\
\hline \multicolumn{18}{|c|}{ planning tools } \\
\hline P01 brief document & 80 & & 20 & 50 & 55 & & 45 & 15 & 70 & & & & 15 & & & & \\
\hline P02 concept design stage kick-off meeting & 15 & 75 & 10 & & & & & & 100 & & & & & & & & \\
\hline P03 $\quad$ tender design stage kick-off meeting & 25 & & 75 & & & & & & 100 & & & & & & & & \\
\hline P04 detailed design stage kick-off meeting & 15 & 55 & 25 & & & & & & 100 & & & & & & & & \\
\hline P05 design change workshop & 35 & & 65 & & & & 30 & 15 & & & & 70 & 30 & & & & \\
\hline P06 master design programme & 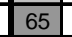 & 15 & 20 & 40 & & 30 & & & 30 & & & & 40 & & 55 & 25 & \\
\hline P07 consultant benchmarking & 5 & 85 & 10 & & & & & & - & & & 100 & & 100 & & & \\
\hline P08 consultant interviews & 5 & 85 & 10 & & & & & & & & 100 & 100 & & & & & \\
\hline P09 discipline design programme & 65 & \begin{tabular}{|l|l|l|l|l|}
10 \\
\end{tabular} & 25 & 55 & & 40 & & & 45 & 25 & 10 & & 15 & & 25 & 90 & \\
\hline P10 $\quad$ job description & 5 & 95 & & & & & & & & & & & & & & & \\
\hline \multicolumn{18}{|c|}{ co-ordination tools } \\
\hline C01 information transfer schedule & 85 & & 15 & 60 & 5 & 25 & & & 60 & & 55 & & & & 10 & 10 & \\
\hline C02 work package control document & 75 & & 25 & 65 & 55 & 5 & 25 & 5 & 45 & & 15 & & 20 & 5 & & & \\
\hline 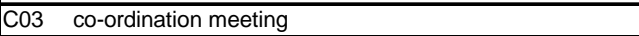 & 95 & & 5 & & & 75 & 5 & & 35 & 10 & & & 10 & & & & \\
\hline \begin{tabular}{|l} 
C04 \\
design workshop
\end{tabular} & 65 & & 35 & 25 & & 30 & 15 & 10 & & 75 & & & 60 & & & & \\
\hline C05 staged information delivery & 40 & 5 & 55 & 75 & 15 & & 50 & 15 & & & & & 15 & 15 & & & \\
\hline $\begin{array}{|ll|}\text { C06 } & \text { fix information } \\
\end{array}$ & 40 & 5 & 55 & 50 & & & 50 & 15 & & & & & 15 & & & & \\
\hline C07 interface schedule & 40 & 5 & 55 & & & 25 & & & 65 & & & & 15 & & & & \\
\hline \multicolumn{18}{|c|}{ development tools } \\
\hline D01 value analysis & 45 & & 55 & 45 & 65 & & & 55 & & 35 & & & & & & & \\
\hline D02 brainstorming & 65 & 15 & 20 & 15 & 15 & & & & 10 & 85 & & & 15 & & & & \\
\hline \begin{tabular}{|ll} 
D03 & decision matrix \\
\end{tabular} & 5 & \begin{tabular}{|c|}
60 \\
\end{tabular} & 35 & & & & & & & & & & & 100 & & & 100 \\
\hline D04 task force meeting & & \begin{tabular}{|l|l|l|l}
50 & \\
\end{tabular} & 50 & & & & & & & & & & & & & & \\
\hline D05 $\quad$ design review document & 30 & \begin{tabular}{|l|l|l|l|}
15 \\
\end{tabular} & 55 & 50 & 100 & & 15 & 35 & & & 15 & & & & & & \\
\hline D06 design proposal document & \begin{tabular}{l|l}
30 \\
\end{tabular} & 15 & 55 & 85 & 65 & & 35 & 35 & & & & & & & & & \\
\hline \multicolumn{18}{|c|}{ monitoring tools } \\
\hline M01 progress report & 75 & & 25 & 55 & & 55 & & & \begin{tabular}{|l|l|l|l|}
20 \\
\end{tabular} & 45 & 60 & & & & & & \\
\hline M02 progress meeting & 80 & & 20 & 65 & & 50 & & & 40 & 50 & 75 & & & & & & \\
\hline cumulative weighted $\%$ of $t$ & s impac & act ide & entifi & ed ag & jains & $t$ all & prac & tices & and $t$ & ools & & & & & & & \\
\hline weighted score & & & & 33 & 6 & 5 & 4 & 2 & 14 & 7 & 5 & $\overline{4}$ & 3 & 3 & 1 & 1 & \\
\hline cumulative weighted percentage score & & & & 66 & 78 & 88 & 95 & 100 & 71 & 80 & 86 & 91 & 94 & 96 & 98 & 99 & 100 \\
\hline
\end{tabular}

Table 4: Impacts Delivered by Design Management Practices and Tools 

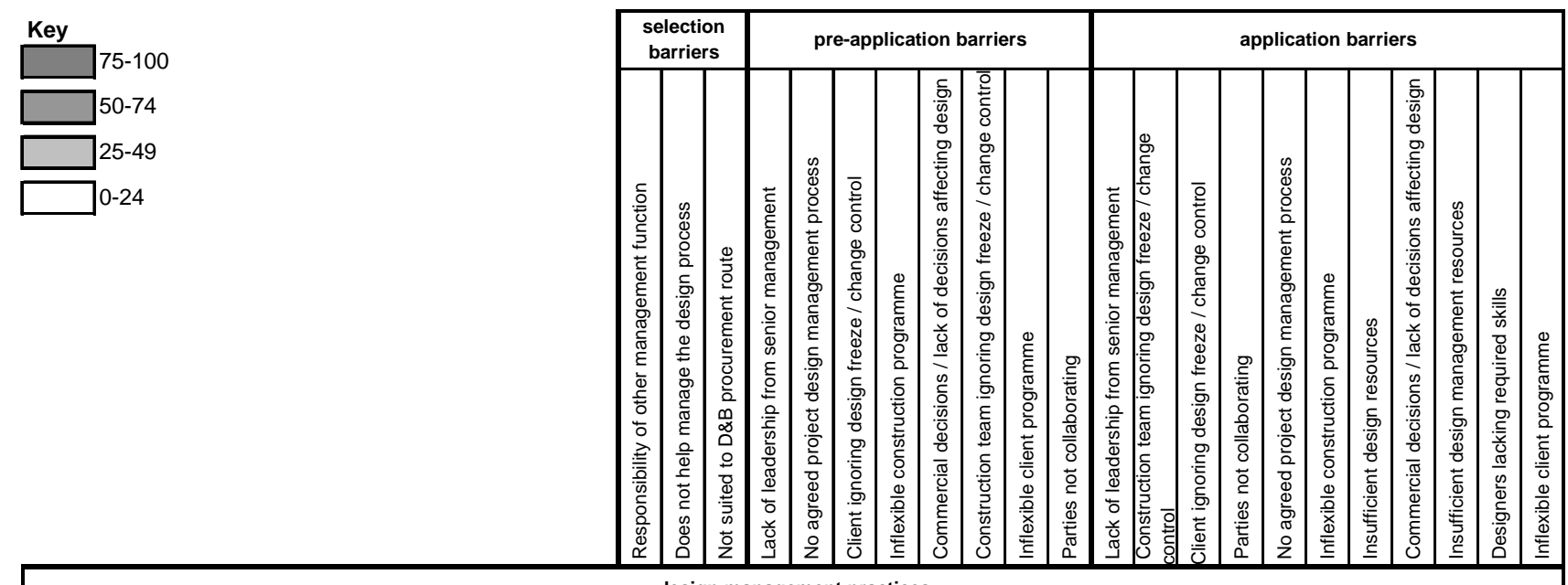

\begin{tabular}{|c|c|c|c|c|c|c|c|c|c|c|c|c|c|c|c|c|c|c|c|c|c|c|}
\hline \multicolumn{23}{|l|}{ 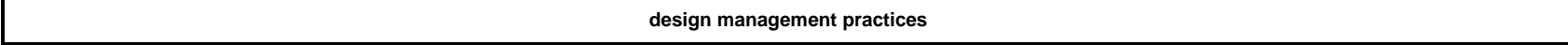 } \\
\hline Rigorous team selection based on range of criteria & 100 & & & 100 & & & & & & & & & & & & & & & & & & \\
\hline Capturing, clarifying and ownership of stakeholder requirements & & & & 25 & 25 & & & 25 & & & & & 5 & 15 & 20 & & & & & & & \\
\hline Understanding the process of design in detail & & & & & & & & & & & & 10 & & & 20 & & 10 & 10 & 5 & & 5 & \\
\hline Allow adequate design time & & & & 15 & & 15 & 30 & & & 30 & & 25 & 25 & 10 & 40 & & 25 & 15 & 25 & 10 & & 15 \\
\hline Plan the design in detail and collaboratively & & & & 50 & 25 & & 25 & 25 & & & & 20 & 5 & 5 & 30 & 5 & 5 & 15 & & 5 & 5 & \\
\hline Integrate design, procurement and construction activities & & & & 35 & & & 35 & & & & & 20 & 10 & 5 & 10 & 10 & 5 & 10 & 5 & 5 & 10 & \\
\hline Progressive freezing of design details & & & & 25 & & & & & & & & 25 & 40 & 40 & 5 & 15 & & & & & & \\
\hline Be more specific with design team scope of works & & & & 50 & & & & & & & & 10 & & & & 15 & & 5 & 10 & 5 & 5 & \\
\hline Control issue of deliverables and information & & & & 50 & & & & & & & & 15 & & 10 & 10 & 15 & & 20 & & 5 & & \\
\hline Manage interfaces & & & & 40 & 60 & & & & & & & 15 & 15 & 5 & 35 & 15 & 5 & 5 & & 5 & & \\
\hline Investigate and control potential design changes & & & & 30 & 15 & 30 & & & 15 & & 15 & 40 & 40 & 40 & 15 & 25 & & 10 & & & & \\
\hline Focus development effort early in the process & & & & 25 & 50 & 25 & & & 25 & & & 25 & 30 & 25 & 30 & 15 & 5 & 5 & 20 & 5 & & \\
\hline Involve parties at the right time in the process & & & & 25 & 50 & & & & & & & & 5 & & 15 & & & & 15 & & & \\
\hline Monitor all design tasks and deliverables & & & & 25 & 25 & & & & & & & 15 & & & & & & 5 & 5 & & 5 & \\
\hline \multicolumn{23}{|c|}{ planning tools } \\
\hline P01 brief document & & & & 25 & 75 & & & & & & & & & & & & & & & 5 & & \\
\hline P02 concept design stage kick-off meeting & & & 100 & & & & & & & & & & & & & & & & & & & \\
\hline P03 tender design stage kick-off meeting & & & & 40 & 35 & & & & & & 5 & 40 & & & & 20 & & & & & & \\
\hline P04 detailed design stage kick-off meeting & 10 & & 90 & 20 & 20 & & & & & & & & & & & 35 & & & & & & \\
\hline P05 design change workshop & & & & 15 & 25 & 40 & & & & & & 15 & 45 & 30 & & & & & & & & \\
\hline P06 master design programme & 100 & & & 25 & 25 & & & & & & & 10 & & 15 & 10 & & 25 & 15 & 10 & 10 & & \\
\hline P07 consultant benchmarking & 100 & & & 50 & 50 & & & & & & & & & & & & & & & & & \\
\hline P08 consultant interviews & 100 & & & 50 & 50 & & & & & & & & & & & & & & & & & \\
\hline P09 discipline design programme & & & & 20 & 20 & & & & & & & 25 & 10 & & 15 & & 10 & 25 & & & & \\
\hline P10 job description & & 60 & & & & & & & & & & & & & & & & & & & & \\
\hline \multicolumn{23}{|c|}{ co-ordination tools } \\
\hline C01 information transfer schedule & & & & & & & & & & & & 5 & & & 10 & & & 5 & & & & \\
\hline C02 work package control document & & & & & & & & & & & & 5 & & & & & & & & & & \\
\hline C03 co-ordination meeting & & & & & & & & & & & & 15 & 5 & & 10 & & & & & 5 & & \\
\hline C04 design workshop & & & & & & & & & & & & 10 & & & & & & & & & & \\
\hline C05 staged information delivery & & & & & & & 10 & & & & & & & & & & & & & & & \\
\hline C06 fix information & 100 & & & 10 & 10 & & & & & & & 15 & 25 & 25 & & & & & & & & \\
\hline C07 interface schedule & & & & & 45 & 10 & & & 10 & & & 15 & 15 & 15 & & & & & & & & \\
\hline \multicolumn{23}{|c|}{ development tools } \\
\hline D01 value analysis & & & & 10 & 55 & 10 & & & & & & 20 & 10 & & 10 & 45 & & & & & & \\
\hline D02 brainstorming & & 65 & & & & & & & & & & & & & & & & & & & & \\
\hline D03 decision matrix & & 100 & & & & & & & & & & & & & & & & & & & & \\
\hline D04 task force meeting & & 80 & & & & & & & & & & & & & & & & & & & & \\
\hline D05 design review document & & & & & 20 & & & & & & & & & & & & & & & & & \\
\hline D06 design proposal document & & & & & 45 & & & & & & & & & & & 15 & & & & & & \\
\hline \multicolumn{23}{|c|}{ monitoring tools } \\
\hline M01 progress report & & & & & 20 & & & & & & & & & & & 5 & & & & & & \\
\hline M02 progress meeting & & & & & 25 & & & & & & & & & & & & & & & & & \\
\hline \multicolumn{23}{|c|}{ cumulative weighted $\%$ of times impact identified against all practices and tools } \\
\hline weighted score & 11 & 4 & 2 & 7.7 & 7.7 & 1.1 & 1.0 & 0.6 & 0.4 & 0.3 & 0.1 & 2.6 & 2.3 & 1.9 & 1.8 & 1.4 & 0.9 & 0.9 & 0.7 & 0.5 & 0.3 & 0.1 \\
\hline cumulative weighted percentage score & 63 & 88 & 100 & 41 & 82 & 87 & 93 & 96 & 98 & 99 & 100 & 20 & 37 & \begin{tabular}{|l|}
51 \\
\end{tabular} & \begin{tabular}{|l|}
65 \\
\end{tabular} & \begin{tabular}{|l|}
75 \\
\end{tabular} & 82 & 89 & \begin{tabular}{|l|}
94 \\
\end{tabular} & 98 & 100 & 100 \\
\hline
\end{tabular}

Table 5:Barriers Experienced by Design Management Practices and Tools 
P01 Brief document, P06 Master design programme, P09 Discipline design programme were effective planning tools, positively affecting the performance of over half interviewees and delivering critical and supportive project impacts. P06 could perhaps have been more successful but was affected at the pre-application stage by the lack of leadership and agreed design management processes to get project teams to prepare and buy into detailed design planning. The application of P03 Tender Kick-off Meeting and P05 Design Change Workshop had some success. However, use and impact was limited with the former providing a supportive impact and the latter three critical impacts. P03 was affected by the lack of leadership and agreed design management processes at preapplication and application stages. Practitioners were dissuaded from using P05 through a lack of agreed design management process framework on which to base the tool and the client issued changes by instruction, thus ignoring design freeze and change control.

Few interviewees used P02 and P04 concept and detailed design kick-off meeting. It appears that they do not fit in with the company's role within the D\&B procurement route. The company is rarely involved early enough in a project to use P02. In Design and Build project interviewees noted no clear step between tender and detailed design thus P04 was unnecessary and P03 Tender design kick-off meeting was sufficient.

Many did not use P10 Job Description, D03 Decision Matrix and D04 Task Force Meeting saying they did not help to manage the design process. Interviewees could not see any real application for D03 and D04 the tools in their work. P10 was considered too structured for the varied and fluid role of the design manager. Several respondents stated the Design Management Handbook itself provided sufficient guidance while allowing them to use professional judgement to respond to the project needs.

All co-ordination tools delivered critical and supportive impacts - illustrating their importance to effective design management, the tools providing the most critical impacts were C05 Staged Information Delivery, C02 Work Package Control Document and C03 Co-ordination Meeting. This establishes them as crucial co-ordination tools. Barriers affected few tools, with only C06 Fix Information significantly affected by the construction team and client ignoring design freeze / change control during application. C05 Staged Information Delivery, C06 Fix Information and C07 Interface Schedule were used by less than half of interviewees, even though they were effective tools. The lack of agreed design management processes did not provide the framework in which to apply C07. No major barriers were reported for C05 and C06. The only explanation interviewees offered is that while they are useful tools, they are not likely to be used as much as say P06 Master Design Programme or B01 Brief Document.

Development tools that can be considered crucial because they provided critical impacts were D01 Value analysis, D02 Brainstorming, D05 and D06 Design review and proposal documents. They helped deliver the design on time, meet all client and budget requirements. However, less than a third of respondents used D05 Design review document and D06 Design proposal document. While no significant barriers affected D05, interviewees suggested that while useful the tool is not one that would be used as much as P06 master design programme or P01 brief document. The only significant barrier affecting D06 was the lack of agreed project design management process to make the project team buy into its use. This barrier also affected the use of D01, value analysis at both pre-application and application stages. 
The majority of interviewees used M01 and M02 monitoring tools. They help deliver the design on time and ensure it is co-ordinated - marking them as essential tools.

In conclusion, all design management practices apart from Rigorous Team Selection, planning tools - P01, P05, P06, P09, all co-ordination tools, development tools - D01, D02, D05, D06 and all monitoring tools - M01, M02, provided critical impacts and therefore are critical to design management.

Adequate design time, planning the design in detail and collaboratively, managing interfaces, investigating and controlling potential design changes and focusing development effort early in the process were affected by one principal barrier at the preapplication stage and four barriers in application. P02 and P04 concept and detailed design kick-off meeting are not suited to D\&B procurement route. P10 Job Description, D03 Decision Matrix, D04 Task Force Meeting do not help to manage the process. P05 Design change workshop, D01 Value Analysis, C07 Interface schedule are affected by the lack of agreed processes.

\subsection{Critical Impacts Delivered}

Figure 2 illustrates the most frequently identified critical impacts that the practices and tools have delivered. The $80 \%$ cumulative weighted score shows that a timely delivered designs and a design meeting client requirements are the most frequently delivered critical impacts. By considering the cumulative impact reported by $75 \%$ or more of the respondents, then $80 \%$ of responses also ensure a co-ordinated design and fewer late design changes. Therefore, critical impacts delivered by the practices and tools are a timely delivered design, a design meeting client requirements, a co-ordinated design and fewer late design changes.

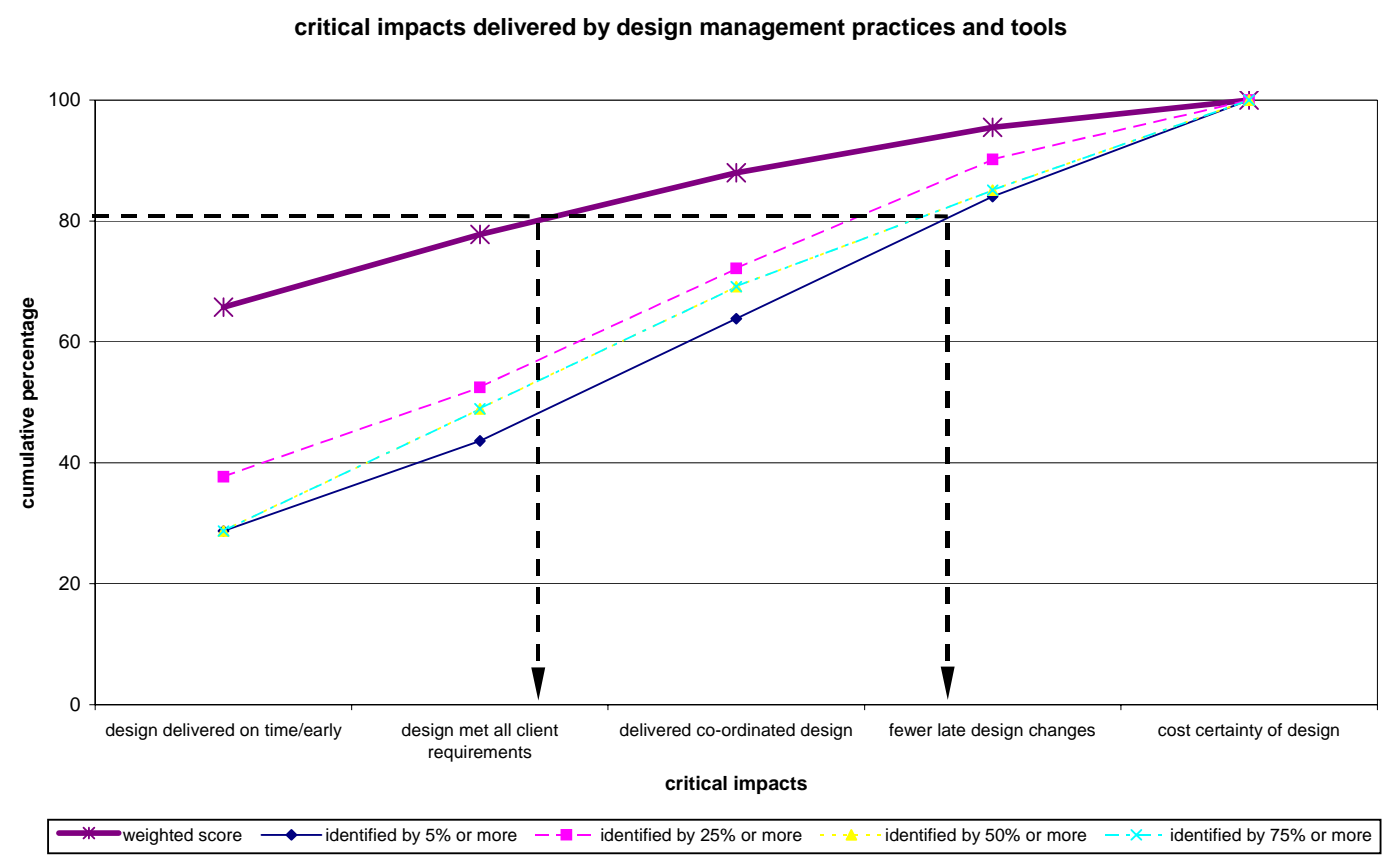

Figure 2: Critical impacts delivered by design management practices and tools 
It is concerning that few practices and tools helped provide cost certainty of design, as it is such a crucial aspect of any project. However, this can be tempered by the fact that cost control is seen as a commercial team task rather than belonging to the design manager. This is supported by the case study findings that the commercial team needed to modify commercial processes and their cost plan to align with the new design management processes.

\section{BARRIERS TO IMPLEMETING PRACTICES AND TOOLS}

\subsection{Selection Barriers}

Selection barriers are clearly significant when experienced as they prevent high proportions of users from using practices and tools in the first place. However, they do not occur in the frequencies of pre-application and application barriers, with only 11 significant occurrences of selection barriers affecting 11 practices and tools. Preapplication and application barriers had 43 and 21 significant instances where they affected the performance of 23 and 13 practices and tools respectively. Therefore, while selection barriers are very disruptive when encountered, they are not often a problem for design management practices and tools.

\subsection{Pre-application and Application Barriers}

Pre-application barriers accounting for $80 \%$ of the cumulative weighted score (Table 5) are a lack of leadership from senior management and no agreed design management processes. Therefore, these are the critical pre-application barriers preventing the majority of users trying to implement new design management processes.

Application barriers accounting for $80 \%$ of the cumulative weighted score (Table 5) are a lack of leadership from senior management, construction team and client ignoring design freeze / change control, parties not collaborating, no agreed design management processes and inflexible construction programme. Therefore, these are the critical application barriers affecting the operation of design management processes and mainly affect practices and planning tools.

When pre-application and application barriers are considered in combination (Figure 3), the key barriers accounting for $80 \%$ of the cumulative weighted score represent the critical barriers affecting the practices and tools throughout the design process. They are:

- a lack of leadership from senior management;

- no agreed project design management process;

- client ignoring design freeze / change control; and

- construction team ignoring design freeze / change control.

However, the only two barriers apparent at both pre-application and application stages were a lack of leadership from senior management, and agreed design management process. Therefore, they are the key barriers affecting the use of design management practices and tools throughout the design process. 


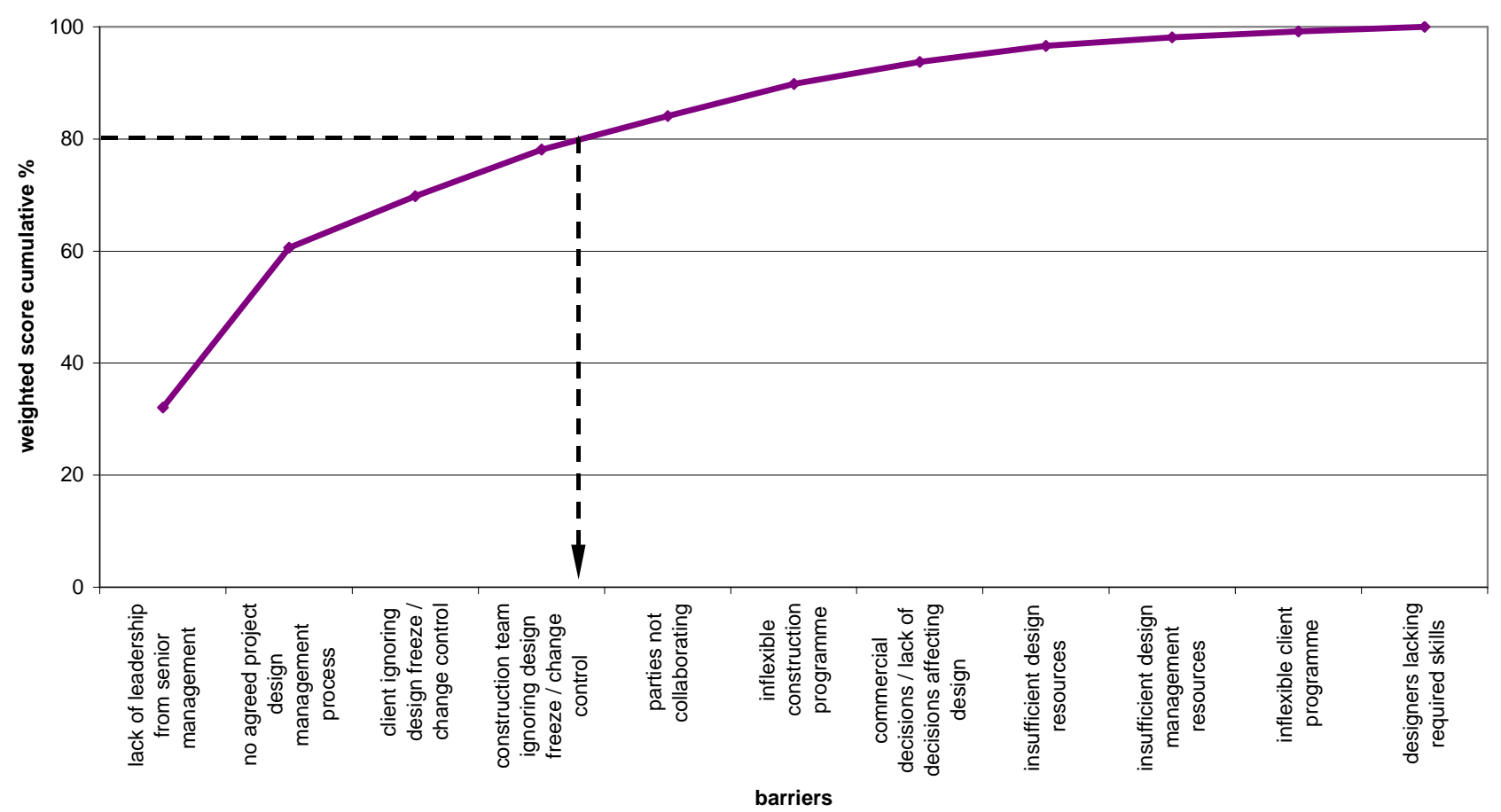

Figure 3: Pre-application and application barriers affecting design management practices and tools

\subsection{Hierarchy of Pre-Application and Application Barriers}

Figure 4 is a matrix where barriers in columns can lead to barriers in the rows and illustrates the pre-application / application barrier hierarchy from interview comments. There are two clear groups of barriers that can be identified. The first group can be defined as primary barriers that can cause the other group - the secondary barriers.

The most influential primary barrier is the lack of leadership from senior management. It is potentially the pre-cursor to the other eleven barriers. For example, in the case of an inflexible client programme and the client ignoring the design freeze process, a D\&B contractor has the opportunity to illustrate to the client the benefits of providing a more flexible programme and buying into the design freeze process. However, interview and case study experience suggest that this opportunity could be taken more often.

A lack of agreed design management processes, as the second most influential barrier has the potential to directly cause four other barriers and indirectly a further four barriers. The lack of leadership from senior management and a lack of agreed design management processes are both internally originating barriers, as are a further five out of the six primary barriers. In conclusion, it is clear that the company has significant influence over pre-application and application barriers and therefore has the capacity to reduce the effect of the barriers and improve the success of design management practices within projects. 


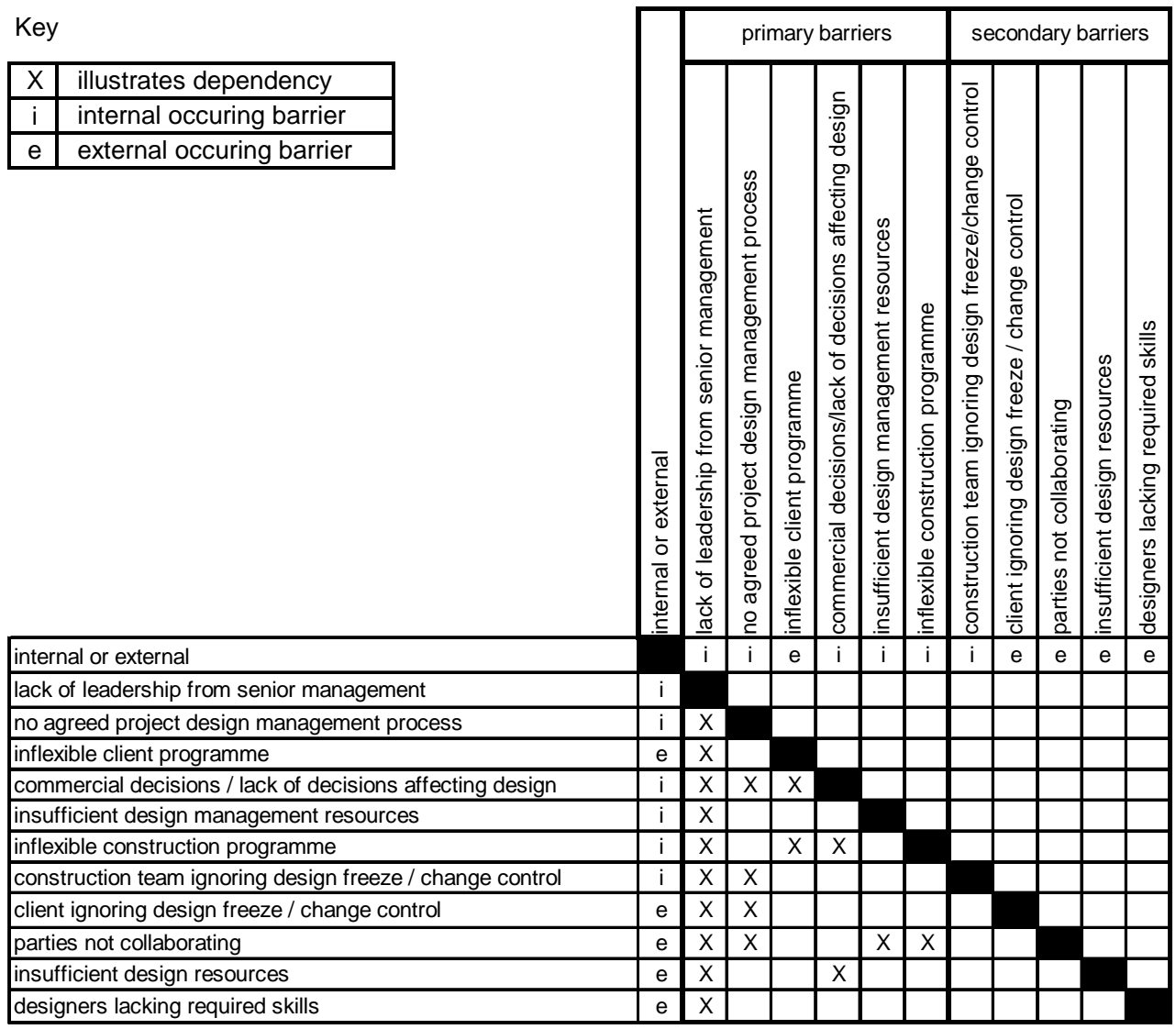

Figure 4: Matrix illustrating hierarchy of pre-application and application barriers

\section{DESIGN MANAGEMENT HANDBOOK MODIFICATIONS}

Figure 5 outlines the contents of the Design Management Handbook trialed throughout the company and modifications, additions and withdrawals based on interview comments and case study experiences. The tools P10 Job Description, D03 Decision Matrix and D04 Task Force Meeting will be removed from future versions of the Handbook as the majority of interview respondents did not use them, claiming they do not help to manage the design process.

Several modifications and additions were suggested. It was suggested to combine the designer's brief section of P01 Brief Document with C02 Work Package Document to streamline the briefing document issued to designers. This was undertaken for the case study project and to date has been welcomed by the project team.

The handbook size (256 pages) initially overwhelmed some interviewees believing they were expected to read it from cover to cover rather than as a reference tool to provide support where they need it. Therefore, the introductory section will be modified by explaining how best to use the Handbook. Other suggestions were to reinforce the need to rigorously review stakeholder requirements early in the project before contract close, as it is a key project risk area for the company, and provide more guidance on the level of design management resources required for a project. 
A Project Design Management Plan was developed out of case study and interview findings which highlighted the need for a design management framework in which to define the practices and tools to be deployed on a project. It illustrates which, how and the format of the practices and tools to be deployed based on specific project processes and contractual requirements. It has been well received on the case study project by the team, designers and the client by providing clarity of how the design process will be executed and a framework for the design management practices and tools.

Also to be included are a suite of Design Process Performance Indicators. These are part of associated research at the company and will be added once complete.

Remaining additions were not design management activities as such, but rather activities carried out by other disciplines during the design process. Respondents recognised that commercial and procurement processes needed modification to align with the new design management processes. Also a model designers' contract was needed to limit delays in agreeing a contract that is acceptable to both parties.

In conclusion, the changes made were relatively small in number and most were minor modifications. The main changes were the removal of three tools and the provision of a PDMP to implement the Handbook practices and tools on projects. Significantly other project processes are now aligning with the new DM processes. 


\begin{tabular}{|c|c|c|c|c|c|c|}
\hline \multirow{2}{*}{\multicolumn{2}{|c|}{ handbook section }} & \multirow[t]{2}{*}{ topics cover and tools provided } & & & & \multirow[b]{2}{*}{ reason } \\
\hline & & & modifications & additions & removals & \\
\hline & Introduction & $\begin{array}{l}\text { origins of handbook, intended readership, } \\
\text { handbook structure, contact information }\end{array}$ & & $\begin{array}{l}\text { Explain correct way to } \\
\text { use handbook as a } \\
\text { reference tool }\end{array}$ & & $\begin{array}{l}\text { Handbook size can be } \\
\text { overwhelming and } \\
\text { barrier to use }\end{array}$ \\
\hline & Design management & $\begin{array}{l}\text { The need for and what is design } \\
\text { management? } \\
\text { Nature of the design process } \\
\text { Why current design management goes } \\
\text { wrong } \\
\text { How can we better manage the design } \\
\text { process? }\end{array}$ & & & & \\
\hline 2 & The design process & $\begin{array}{l}\text { Nature of the process } \\
\text { Involve parties at the right time } \\
\text { Allow adequate design time } \\
\text { Engender common design processes }\end{array}$ & & & & \\
\hline \multirow[t]{3}{*}{3} & \multirow[t]{3}{*}{$\begin{array}{l}\text { Stakeholders objectives, } \\
\text { briefs and tasks }\end{array}$} & $\begin{array}{l}\text { The need to, barriers to and incorporating } \\
\text { stakeholder needs in the design }\end{array}$ & & & & \\
\hline & & \begin{tabular}{|ll} 
P01 & Brief document \\
P02 & Concept design kick-off meeting \\
P03 & Scheme design kick-off meeting \\
P04 & Detailed design kick-off meeting
\end{tabular} & $\begin{array}{l}\text { Combine design } \\
\text { discipline part of brief } \\
\text { document with work } \\
\text { package document }\end{array}$ & & & $\begin{array}{l}\text { Streamline designer } \\
\text { briefing documentation }\end{array}$ \\
\hline & & & & \begin{tabular}{|l|} 
Outline how to review \\
stakeholder \\
requirements, removing \\
ambiguity in design brief \\
docs
\end{tabular} & & $\begin{array}{l}\text { key risk area needing } \\
\text { careful management }\end{array}$ \\
\hline \multirow[t]{2}{*}{$\overline{4}$} & Managers and structures & $\begin{array}{l}\text { The need for, barriers to, qualities of and } \\
\text { training good design managers }\end{array}$ & & & P10 Job description & $\begin{array}{l}\text { Does not help manage } \\
\text { the design process }\end{array}$ \\
\hline & & P10 Job description & & & & \\
\hline \multirow[t]{2}{*}{5} & \multirow[t]{2}{*}{ Selecting team members } & $\begin{array}{l}\text { Importance of the team, necessary } \\
\text { relationships and attitudes, skills and } \\
\text { competencies }\end{array}$ & & $\begin{array}{l}\text { Model contract for } \\
\text { designers }\end{array}$ & & $\begin{array}{l}\text { Need to align } \\
\text { commercial with DM } \\
\text { issues }\end{array}$ \\
\hline & & \begin{tabular}{|ll} 
P07 & Consultant benchmarking \\
P08 & Consultant interviews
\end{tabular} & & $\begin{array}{l}\text { Procurement schedule } \\
\text { for subcontract design }\end{array}$ & & $\begin{array}{l}\text { Need to align } \\
\text { procurement with DM } \\
\text { issues }\end{array}$ \\
\hline \multirow[t]{2}{*}{6} & \multirow[t]{2}{*}{ Planning the design process } & $\begin{array}{l}\text { The need for, barriers to and planning the } \\
\text { design process }\end{array}$ & & $\begin{array}{l}\text { Project design } \\
\text { management plan }\end{array}$ & & $\begin{array}{l}\text { Show how will use DM } \\
\text { ideas and tools on } \\
\text { specific project }\end{array}$ \\
\hline & & \begin{tabular}{|ll} 
P06 & Master design programme \\
P09 & Discipline design programme
\end{tabular} & & & & \\
\hline & Ensuring design delivery & $\begin{array}{l}\text { The need for, barriers to and effective } \\
\text { design delivery }\end{array}$ & $\begin{array}{l}\text { Combine design } \\
\text { discipline part of brief } \\
\text { document with work } \\
\text { package document }\end{array}$ & & & $\begin{array}{l}\text { Streamline designer } \\
\text { briefing documentation }\end{array}$ \\
\hline & & 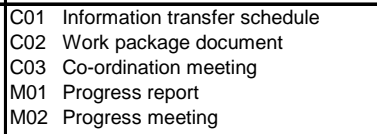 & & \begin{tabular}{|l} 
Design process \\
performance indicators
\end{tabular} & & $\begin{array}{l}\text { Next phase of design } \\
\text { management } \\
\text { development }\end{array}$ \\
\hline \multirow{2}{*}{\multicolumn{2}{|c|}{8 Managing information flow }} & $\begin{array}{l}\text { The need for, barriers to and effective } \\
\text { information flow management }\end{array}$ & & & & \\
\hline & & $\begin{array}{ll}\text { C04 } & \text { Design workshop } \\
\text { C05 } & \text { Staged information delivery } \\
\text { C06 } & \text { Fix information } \\
\text { C07 } & \text { Interface schedule }\end{array}$ & & & & \\
\hline & \multirow[t]{4}{*}{ Developing the design } & 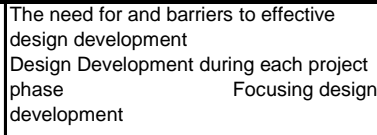 & & & D03 Decision matrix & $\begin{array}{l}\text { Does not help manage } \\
\text { the design process }\end{array}$ \\
\hline & & \begin{tabular}{|ll} 
D01 & Value analysis \\
D02 & Brainstorming \\
D03 & Decision matrix \\
D04 & Task force meeting \\
D05 & Design review document \\
D06 & Design proposal document
\end{tabular} & & & D04 Task force meeting & $\begin{array}{l}\text { Does not help manage } \\
\text { the design process }\end{array}$ \\
\hline & & & & $\begin{array}{l}\text { Outline how to undertake } \\
\text { cost control of design } \\
\text { development }\end{array}$ & & $\begin{array}{l}\text { Need to align } \\
\text { commercial with DM } \\
\text { issues }\end{array}$ \\
\hline & & & & Cost plan & & \begin{tabular}{|l} 
Need to align \\
commercial with DM \\
issues
\end{tabular} \\
\hline \multirow{2}{*}{\multicolumn{2}{|c|}{10 Design changes }} & $\begin{array}{l}\text { The effect of, barriers to, and managing } \\
\text { design change proposals Identifying and }\end{array}$ & & & & \\
\hline & & P05 Design change workshop & & & & \\
\hline
\end{tabular}

Figure 5: Design Management Handbook Contents, Modifications, Additions and Withdrawals 


\section{DESIGN MANAGEMENT MATURITY ASSESSMENT}

Figure 6 illustrates the three stages of the maturity assessment. The gap between the first and second assessments indicates the change in respondents' perception of the company's design management maturity caused by the awareness training. All maturity scores for design management areas reduced by an average of half a maturity level to 2.2 (18\% reduction), to "Thinking of doing something about it" on the maturity scale (Figure 1). This highlighted inadequate practices, with the perception of the company's design management maturity was better than the reality. Significant reductions were associated with developing the design, and managing design changes (both 0.8 drop) two areas that are absolutely critical to successfully deliver a project. These and other maturity scores set the benchmark from which the company measured impacts of the training initiative.

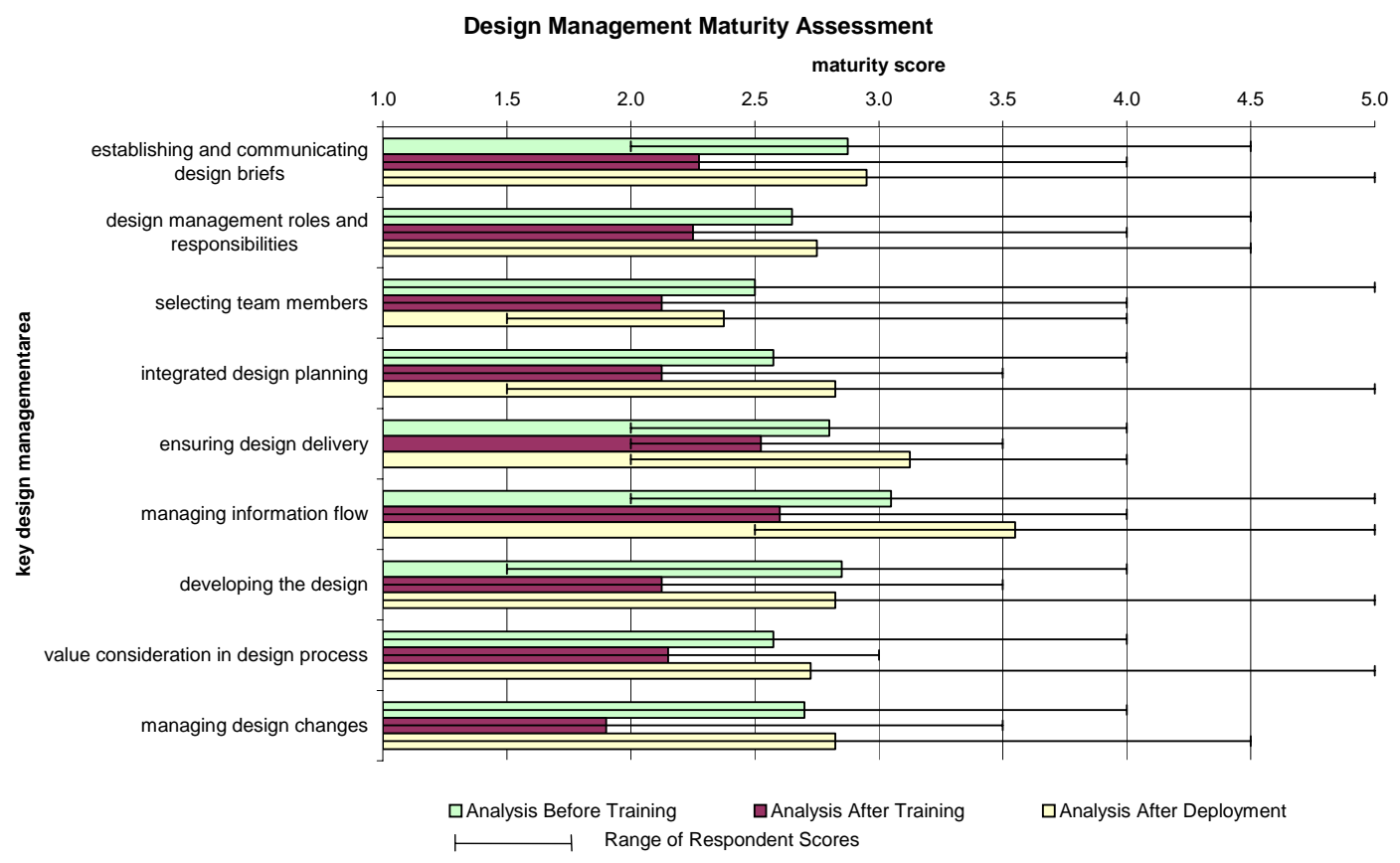

Figure 6: Design Management Maturity Assessment Results

The maturity assessment carried out after the training initiative had been deployed showed that respondents believe the company has improved all design management performance areas since the training started. The maturity score has increased by $29 \%$ from the second assessment to 2.9. This is almost a full level increase in maturity to "Beginning to do something about it". Notably there has been a 36\% average increase to an average maturity score of 3.0 across Establishing and Communicating Design Briefs, Integrated Design Planning, Managing Information Flow, Developing the Design and Managing Design Changes - all fundamental activities to the successful design management. Other processes have also improved, albeit to a lesser degree. The least improved area was Selecting Team Members. This may be due to the fact that only a few respondents were involved in this exercise as it is the responsibility of senior management, yet few felt that this was being done rigorously. 
Many interviewees considered the Design Management Maturity Model useful in helping understand current practices that are no longer working, where improvements are needed and how much they can improve - key factors in promoting change (Filson and Lewis, 2000). One interviewee offered "it shows clearly where we really need to focus our attention to improve performance”. This suggests it is a useful tool in defining and helping to improve design management maturity.

In conclusion, according to the maturity assessment, the training initiative has raised awareness of the true design management performance across the company, and most importantly has delivered design management maturity improvements across the company. However, there is also significant scope for future development as the company reports a maturity score of 2.9 with the short term aim to ensure that all design management practices are being done as normal business (level 4).

\section{CONCLUSIONS}

This paper has reported on the impact of a design management training initiative within a major UK civil and building design and construction company. This has led to several conclusions:

- The Handbook is being used and is useful for diffusing design management practices and tools and the training initiative has improved design management in practice.

- The Design Management Maturity Model can help define and improve design management maturity.

- 30 out of the 39 practices and tools are critical to design management.

- The critical impacts delivered most are a timely delivered design, a design meeting client requirements, a co-ordinated design and fewer late design changes, yet few practices and tools helped provide cost certainty of design.

- Selection barriers can be very disruptive, yet do not occur often.

- Lack of leadership from senior management and no agreed design management processes are the critical pre-application barriers.

- Lack of leadership from senior management, construction team and client ignoring design freeze / change control, parties not collaborating, no agreed design management processes and inflexible construction are the critical application barriers.

- Lack of leadership from senior management and the lack of agreed design management processes are the critical barriers throughout the design process.

- A Design and Build Contractor has the capacity to improve the success of design management practices within projects by reducing the effect of the barriers. 
- Involving client and design team in the change process and using a Project Design Management Plan can help to implement design management practices and tools by overcoming key implementation barriers.

\section{ACKNOWLEDGEMENTS}

The authors would wish to thank Skanska Integrated Projects, Skanska UK Building and the Engineering and Physical Sciences Research Council (EPSRC), which have provided the funding for this work through the Centre for Innovative Construction Engineering at Loughborough University.

\section{REFERENCES}

Austin, S., Baldwin, A., Hammond, J., Murray, M., Root, D., Thomson, D. and Thorpe, A., 2001, Design Chains: A handbook for integrated collaborative design, Thomas Telford, London.

Austin, S.A., Baldwin, A.N., Newton, A.J. 1996, “A data flow model to plan and manage the build design process”, Journal of Engineering Design, Vol. 7, No. 1, pp 317.

Baldwin, J. and Jarrett, N., 2002, Rethinking Construction - Accelerating Change: Compendium of responses to the consultation paper by the Strategic Forum for Construction, Warwick Manufacturing Group, University of Warwick, UK.

Beer, M., Eisenstat, R. A. and Spector, B., 1993, Why change programs don't produce change, from Managing Change (2nd Ed), Mabey C., and Mayon-White, B., (eds), Paul Chapman Publishing, London.

Crawford, J. K., 2002, Project Management Maturity Model: Providing a proven path to project management excellence, Marcel Dekker, New York.

Bibby, L., Bouchlaghem, D., and Austin, S., 2003a, "Design Management in Practice: Testing a Training Initiative to Deliver Tools and Learning”, Construction Innovation, Vol. 3, No. 4.

Bibby, L., Austin, S., Bouchlaghem, N., 2003b, "Defining an improvement plan to address design management practices: a case study of a UK construction company" International Journal of IT in Architecture, Engineering and Construction (IT-AEC), Vol. 1, Issue 1, pp. 57-66.

Bibby, L., Bouchlaghem, N., Austin, S., 2002, “Delivering Learning and Tools to Improve Design Management in Practice”, Proceedings of CIB Conference on Measurement and Management of Architectural Value in Performance-Based Buildings, Hong Kong, May 2002. 
Egan, Sir J., 2002, Accelerating Change: a report by the strategic forum for construction, Rethinking Construction c/o Construction Industry Council, London, UK.

Fellows, R. and Liu, A. 1997, Research Methods for Construction, Blackwell Science, Oxford.

Filson, A. and Lewis, A. 2000, "Cultural issues in implementing changes to new product development process in a small to medium sized enterprise (SME)”, Journal of Engineering Design, Vol. 11, No. 2, pp 149-157.

Freire, J. and Alarcon, L.F. 2000, “Achieving a lean design process” in Proceeding of the $8^{\text {th }}$ International Group for Lean Construction Conference, Brighton, England.

Frost, R.B. 1999, "Why does industry ignore design science”, Journal of Engineering Design, Vol. 10, No. 4, pp 301-304.

Kagioglou, M. Cooper, R., Aouad, G., Hinks, J., Sexton, M., Sheath, D., 1998, “Generic design and construction process protocol final report", The University of Salford, Salford, UK

Kanter, J., 2000, "Have we forgotten the fundamental IT enabler: ease of use”, Information Systems Management, Summer, Pages 71- 77

Kuprenas, J.A., 2003, “Project Management Actions to Improve Design Phase Cost Performance”, Journal of Management in Engineering, January, pp 25-32.

Race, P. 2001, 2000 Tips for Lecturers, Kogan Page, London.

Rosenstock, C. , Johnston, R. \& Anderson, L., 2000, "Maturity model implementation and use: A case study.”, Proceedings of the $31^{\text {st }}$ Annual Project Management Institute 2000 Seminars and Symposium.

Skulmoski, G., 2001, "Project maturity and competence interface, "Cost Engineering”, Vol. 43, No 6, pp11-18.

White, K. 1979, “The Scanlon Plan: causes and correlates of success”, Academy of Management Journal, Vol. 22, June, pp 292-312.

Womack, J. P. and Jones, D. T., 1996, Lean Thinking: Banish Waste and Create Wealth in Your Corporation, Simon \& Schuster, Sydney. 